\title{
Organizational Learning and Self-Efficacy as the mediators in the Organizational Culture impact on the Employee's Performance
}

\author{
Halid Hasan ${ }^{a^{*}}$ \\ ${ }^{a}$ Brawijaya University, Malang, East Java, Indonesia
}

\section{ARTICLE INFORMATION}

\section{ABSTRACT}

\section{Article history:}

Data submission : 10 October 2020

$1^{\text {st }}$ revision: 10 November 2020

Accepted: 16 December 2020

Available online: 30 December 2020

Keywords: organizational culture;

organizational learning; self- efficacy;

employees performance
This study investigated the mediating effects of organizational learning and selfefficacy on the relationship between organizational culture and employee performance. The sample consisted of 172 employees of government owned banking institutions in Malang district, Indonesia. Results, using path analysis reveals that all the variables examined positively and significantly affect employee performance. This study found that organizational learning and self-efficacy mediated the relationship between organizational culture and employee performance.

2020 FIA UB. All rights reserved.

\section{Introduction}

In an organization, the employees apply the culture implementation as a behavior that will effect in the performance increasing. Wibowo (2012) mentioned that employee's performance determines by both internal and external factor which is one of them is the organizational culture. Organizational culture is related to the individual behavior and the interaction among them in one organization (Schein, 2010). Some previous studies measured the effect of organizational culture on the performance of the employees (Nikpour, 2017; Syafii et al, 2025 and Saeed, 2013) by using some indicators to see the significance of the influence. The results found that organizational culture has direct significant influence toward the performance. Organizational culture itself is created to make performance as a need. It is in line with Liliweri's statement (2002) that employee is a human being that has culture potency such as thought (creating), feeling and desire (intention) that later end up with initiative.

Another internal effect is self-efficacy. Self-efficacy defined as someone's belief on the chance to be success in a certain task (Kreitner, 2010). Based on Bandura (1997), self-efficacy reflects an individual's belief in his/her ability in doing certain task in a specific working level. It is an important motivation (Gist, 1992). Selfefficacy influences someone in making a choice, purpose, emotional respond, and effort in solving problem and keep on preserved. The basis of self-efficacy us the ability and the past performance and they have positive influence on it (Bandura, 1986). Later, Lee and Bobke
(1994) said that mood could also affect self-efficacy: happiness can cause higher self-efficacy. Other researches done by Tim (2013); Lis (2016); Olido (2015); Salman (2016) stated that self-efficacy affect the employee's performance.

Employee performance is also formed from the organizational learning through the created culture. Some studies tested the influence of organizational learning toward employee performance since organizational learning assumed in giving positive impact to the organization in the future. As mentioned by Nafei (2015), Gomes et al (2017), employee who has willing to study about the organizational source, visible or invisible, gives positive impact on his/her performance, which also effects on the organizational performance by giving sustainable competitive advantage.

Organizational learning is a process instead of a goal, so it requires changes in the organizational culture, which are done by, be accustomed to learn, to change and to develop constantly. Learning culture that attached on the employee as the organizational entity seen as a process that should be taken to give positive impact on the employee to make them more independent, ready to develop in the community which will contribute to their working performance.

Bank is one of the vital organizational, all people need the back service as the currency provider and ease some transaction such as property credit, pay the school fee, bills for water, electricity and phone account and other needs, and also help people to invest. High competition requires banks to always be able to adapt to 
any changes and technological developments to improve service quality. Employees are an asset as a driver of the banking business process. Employee management is important, it requires management commitment to manage employees not only for the sake of organizational performance, but also to provide opportunities for employees to develop their careers and competencies.

Especially with the current phenomenon, that bank employees are among the professions affected by the 4.0 industrial revolution, so that employees should not lose compare to machines. There are some other sides where employees still have an important role, such as doing analysis, having deep communication with the customer, dealing with complaints which are some the roles of employees that cannot be replaced by machines. It needs control from management to make sure the balance percentage between the presence of employees and machines in the bank's business process. Creating a conducive culture, providing opportunities for the learning process to every employee have to be done to create self-efficacy and good employee performance, and for sure it will be beneficial for both parties, the organization and employees.

The research was conducted in several governmentowned banking institutions in Malang City and Regency, East Java, Indonesia, with respondents being assistant level employees. The consideration is that governmentowned banking institutions are considered as trustworthy organization, so with the good image, the researcher would like to know whether the organizational culture, learning process has been implemented properly, whether the employees have self-efficacy and good performance as feedback for the award received from the bank where he works. It is necessary to be known that a bank with a good reputation should pay attention to the welfare of its employees, in which knowing the fact is creating for the researcher to find out. Meanwhile, the assistant level employees were chosen on the basis that this level support the day-to-day operations of the bank which meet and serve customers directly.

\section{Theory}

Culture represents the personality of an organization, has a major influence on employee satisfaction and organizational success (Cyert, 1992). Employee satisfaction can result in optimal employee performance. Employee satisfaction can grow because of the commitment of the company to provide an objective employee assessment (Alder, 2001). A strong organizational culture helps in achieving employee performance, it also means the ease of achieving organizational goals and improving organizational performance (Deal\&Kennedy, 1982).

Organizational culture is a system of shared meanings adopted by members that differentiates the organization from other organizations (Robbins and Judges, 2013). Saeed (2013) in his research revealed that culture is a strength inherent in employees as a value, a reference for action that is considered good and right. If there is a decline in culture, then it will have an impact on employee performance, and vice versa, if the culture is well understood and properly implemented by employees, performance will also give positive results. Syafii et al (2015) also conducted research on the relationship between organizational culture and employee performance by stating the results that there was a strong and significant relationship between culture and employee performance. The results of research conducted by Pavlica (2014); Fung (2017) also strengthens the results of previous findings, so that the following research hypothesis can be formulated:

\section{$H I=$ Organizational culture affect significantly on the employee's performance}

Haddad and Taleb (2015) did a study by measuring the relation between self-efficay and the employee' performance by using demographic factors, such as age and status as the study material. The result shows that there is a strong and positive relationship between selfefficacy and the employee's performance. Another research done by Lis and Yunus (2016) in which tested the self-efficacy toward the employee's performance using employee's satisfaction as the moderate variable. The result found that self-efficacy has both direct and indirect impact on the employee's performance which lead to the following hypothesis:

\section{$H 2=$ Self-efficacy significantly affect the employee performance}

Organizational learning is sustainable process that done by all of the organization members that oriented on the process (Garvin, 2000). It is also mentioned that employee who has knowledge about the organization can relate easily with the targeted performance. This result is also supported by Abdi (2018); Jimenez (2010), which mentioned that organizational learning give effect on the employee's performance, so that the following hypothesis is made:

\section{$H 3=$ Organizational learning has significant effect on the employee's performance}

Abdi (2018) and Alsabbagh (2017) conducted research on the relationship between organizational culture and organizational learning and it has been mentioned in the third hypothesis that it is assumed to have significant relationship between organizational learning and employee performance, which is supported by the opinion of Garvin (2000), then the hypothesis is made to test the relationship between organizational culture and employee performance indirectly through organizational learning as a moderator, so the hypothesis is as follows:

\section{$H 4=$ Organizational culture has significant effect on the employee's performance through organizational learning}

As mentioned in the first and second hypothesis that there is assumption that there is an effect of organizational culture toward the employee's performance, and it is assumed that there is an impact of the self-efficacy to the employee's performance and it is supported by the research done by Salman, et al (2016); Tim et al (201), so the following hypothesis is made:

$H 5=\begin{gathered}\text { organizational culture has significant effect on the } \\ \text { employee's performance through self-efficacy }\end{gathered}$ 
Based on the explanation above about the hypothesis, they can be illustrated into the following hypothesis framework:

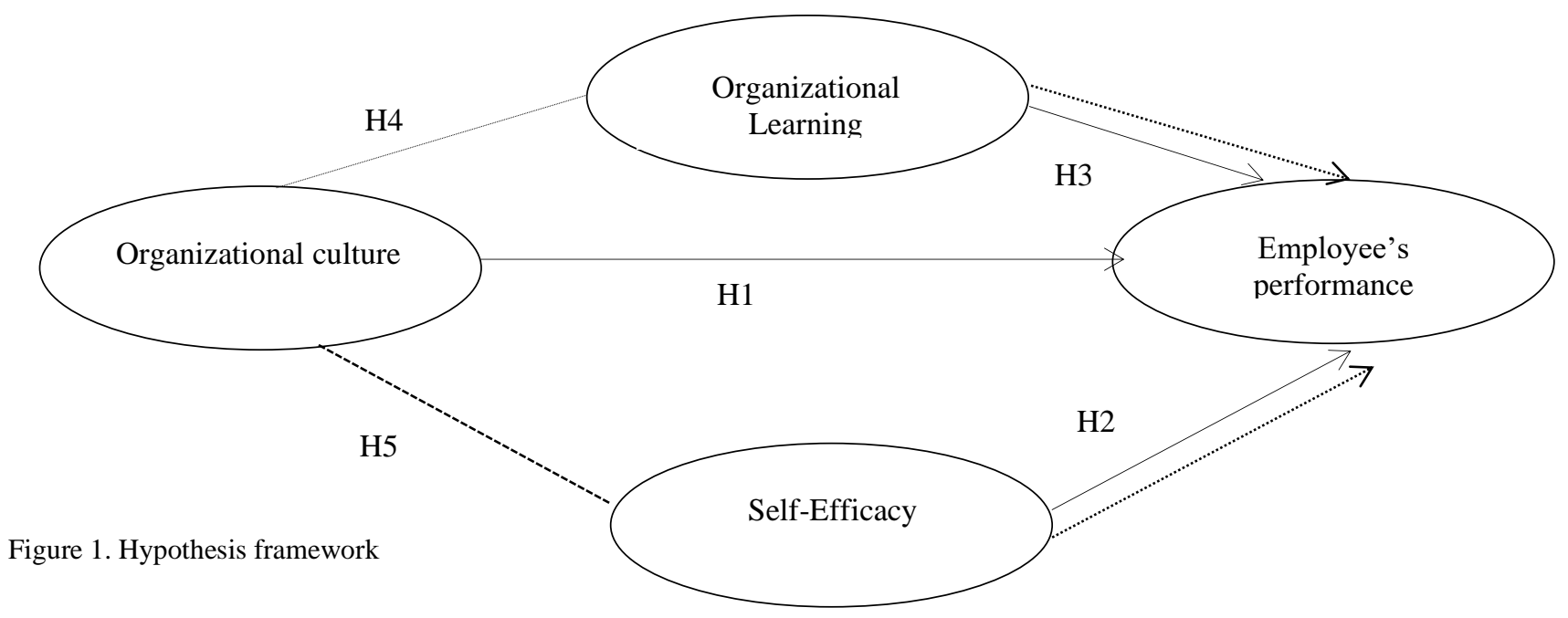

\section{Research Method}

The population in this study were employees of government-owned banking institutions in all cities and districts of Malang, East Java, Indonesia. Questionnaires were given to employees of branch, regional and central offices in each city and district, totaling 34 offices. The survey was conducted from June to September 2019. The total number of questionnaires distributed was 300 questionnaires, of which 284 were returned, and 172 questionnaires were declared eligible for analysis.

The questionnaire used a Likert scale of 5 answer choices, adapting from literature and empirical studies. Measurement of organizational culture follows Denison (1990); measurement of self-efficacy following Bandura (1997); measurement of organizational learning following McShane and Glinow (2010); and employee performance measurement following Fung (2017).

To test the hypothesis, the SEM PLS path analysis was used. The analysis was conducted to determine the direct and indirect relationship between organizational culture, self-efficacy, organizational learning on employee performance.

\section{Results}

Respondent description. A study was conducted by analyzing 172 questionnaires from 300 questionnaires distributed. 172 questionnaires are questionnaires that are considered appropriate to be used as data in this study. The majority of respondents were women (57\%), with an average age of 24-42 years being the largest respondents $(40 \%)$, and respondents with a Diploma 4 / Bachelor's education background were the majority (63\%).

Results of path analysis. The results of the validity and reliability tests show that all variables are declared valid and reliable. The results of the validity test, the value of each variable above 0.5 which is the minimum value of a variable is declared valid, while the reliability test is indicated by the Cronbach's alpha value. The cronbach's alpha value for each variable shows an ideal value of $0.8-0.9$. The following are the results of the validity and reliability test:

Table 1 . Validity and reliability test

\begin{tabular}{lrr}
\hline \multirow{2}{*}{ Variable } & \multicolumn{2}{c}{ Test result } \\
\cline { 2 - 3 } & Validity & Reliability \\
\hline Organizational culture & 0,72 & 0,87 \\
Employee's & 0,96 & 0,96 \\
performance & & \\
Self-Efficacy & 0,74 & 0,82 \\
Organizational & 0,87 & 0,95 \\
Learning & & \\
\hline
\end{tabular}

Next is hypothesis testing. The hypothesis is proven by examining the relationship between variables (direct and indirect effects). The following are the results of the direct and indirect effect testing:

Table 2. Results of test on direct effect of variables

\begin{tabular}{clrc}
\hline Hypotheses & \multicolumn{1}{c}{ Path model } & $\begin{array}{c}\text { Direct } \\
\text { effect }\end{array}$ & $\begin{array}{c}\mathrm{t}- \\
\text { value }\end{array}$ \\
\hline H1 & $\begin{array}{l}\text { organizational } \\
\text { culture } \\
\rightarrow \text { employee's } \\
\text { performance }\end{array}$ & 0,15 & 3,95 \\
H2 & $\begin{array}{l}\text { Self-efficacy } \rightarrow \\
\text { employee's } \\
\text { performance } \\
\text { H3 }\end{array}$ & 0,71 & 10,97 \\
& $\begin{array}{l}\text { Organizational } \\
\text { learning } \rightarrow \\
\text { employee's } \\
\text { performance }\end{array}$ & 0,14 & 2,30 \\
& & & \\
\hline
\end{tabular}

Table 3. Results of test on indirect effect of variables

Hypotheses
Path model

indirect
effect $\quad t$-value




\begin{tabular}{llrr}
\hline H4 & $\begin{array}{l}\text { organizational culture } \rightarrow \text { Organizational learning } \rightarrow \text { employee's } \\
\text { performance } \\
\text { organizational culture } \rightarrow \text { Self efficacy } \rightarrow \text { employee's } \\
\text { performance }\end{array}$ & 0,54 & 9,43 \\
H5 & 0,12 & 2,28 \\
\hline
\end{tabular}

Table 2 shows the coefficient of all three variables that have a significant effect on employees' performance. These three variables positively and significantly affect the performance of employees. Thus, hypotheses 1, 2, and 3 are accepted. Table 3 shows the results of tests on mediating self-efficacy and organizational learning on the relationship between organizational culture and employee's performance. Thus, hypotheses 4 and 5 are accepted $(\mathrm{p}<0.05)$.

\section{Discussion and conclusion}

This research has found that organizational culture positively and significantly affects employee's performance in which the higher the organizational culture, the higher the performance of the employees will be. This finding is supported by previous studies (Cyert, 1992; Deal\&Kennedy, 1982; Robbins dan Judges, 2013; Saeed, 2013; Syafii et al, 2015; Pavlica, 2014; Fung, 2017). Thus, it is suggest that organizations which have a good culture would improve the performance of employees.

Self-efficacy is found to have positive effect on employee's performance. This points out that the indicators of self-efficacy can escalate employee's performance. It means that if many aspects are in accordance with employee expectations and beliefs, the higher the self-efficacy, the better the performance, or vice versa. The findings of the recent study confirmed by previous studies which have revealed that self- efficacy is positively and significantly correlated with employees performance (Haddad dan Taleb, 2015; Lis dan Yunus, 2016; Tims, Bakker\&Derks, 2012; Salman, Khan\&Draz, 2016).

Organizational learning has a positive and significant effect on employee's performance which means that the indicators, included in the organizational learning, can increase employee's performance. This is in line with Garvin (2000) who asserts that organizational learning denotes pleasing work atmosphere, and it is expected by every employee they can perform better performance. The similar finding found by Abdi (2018) and Jimenez (2010), which report that organizational learning has a positive influence on employee's performance.

The study documents about organizational learning mediates the influence of organizational culture on employees performance means that the indicators of organizational culture can enhance employees performance by the effect of organizational learning. The direct effect of organizational culture on employee's performance was $15 \%$ while the indirect effect of organizational culture on employee's performance through organizational learning was $54 \%$. This indicates that the indirect effect of organizational culture on performance is stronger than the direct if it is not supported by the organizational learning. Thus, it is clear that organizational learning can improve the influence of organizational culture and employee's performance which is in line with Abdi (2018); Alsabbagh (2017) which states that although the culture applied by the company is the same for all work units, each employee will vary in performance achievement, depending on the learning process carried out.

The study finds that the self-efficacy statistically mediates the relationship between organizational culture and employee's performance, or we can say that organizational culture indicators can raise employee's performance with the support self-efficacy. The direct effect of organizational culture on employee's performance reaches $15 \%$, whereas the indirect effect of organizational culture on performance through selfefficacy is $12 \%$. There is no significant difference of the direct and indirect effect of the organizational culture toward the employee's performance through selfefficacy. This testing is an experimental testing of the existence of the direct effect of organizational culture and self-efficacy on the employee's performance. It is tested that whether the support of organizational culture on the employee's performance becomes stronger if there is self-efficacy as mediator. And the result finds that the similar effect is made by both direct and indirect one.

The study is aimed to examine the influential factors of the employee's performance. The tests were performed on a sample of 172 questionnaires generated from the banking employees with the level of assistant in the banking organization in a government-owned banking institution in the city and district of Malang, Indonesia. The result found out by using the path analysis which shows that organizational learning and self-efficacy mediates the relationship between organizational culture and employee's performance. Independently organizational culture positively affect employee's performance.

Two limitations emerge and worth noting. First, the study is done by only involved the banking organizations in Malang city and regency. Thus, the result of the study is very specific and suffer from general issues. Second, self-efficacy as a mediator variable in the organizational culture does not show higher value compare to the selfefficacy or organizational culture direct impact on the employee's performance. The respondents are limited to the banking employee owned by the government, which probably can be the cause. It is highly possible that selfefficacy can be the mediator and support the higher value on the impact of organizational culture toward the employee's performance, if the respondent is not limited to the government owned bank.

\section{References}

Abdi, K., et.al .2018. The Effect of Knowledge Management, Organizational Culture, and 
Organizational Learning On Innovarion in Automotive Industry. Journal of Business Economics and Management Volume 19 Issue 1.

Alsabbagh, M. 2017. The Impact of Organizational Culture on Organizational Learning (An Empirical Study on the Education Sector in Damascus City. International Journal of Academic Research in Business and Social Sciences, Vol. 7 (4).

Bandura, A. (1994). Self Efficacy. In V. S. Ramachaudran (Ed.), Encyclopedia of human behavior (Vol. 4, 77-81). New York: Academic Press.

Denison, R. 1990. Corporate Culture and Organizational Effectiveness. New York: John Wiley \& Sons.

Cyert, R. M. and March, J.G. 1992. A Behavioral Theory of the Firm. Englewood Cliffs. NJ: Prentice-Hall.

Ferdinand, A. 2006. Metode Penelitian Manajemen: Pedoman Penelitian untuk Skripsi, Tesis dan Disertai Ilmu Manajemen. Semarang: Universitas Diponegoro.

Fung, C, Sharma, P, Wu, Zan, and Su, Y, 2017, Exploring Service Climate and Employee Performance in Multicultural Service Settings, Journal of Service Marketing, 31/7, 784 - 798.

Garvin, D.A. 2000. Kualitas Produk: Alat Strategi Yang Penting. Jakarta. Free Press. Edisi III.

Haddad, T. 2015. The Impact of Self Efficacy on Performance (An Empirical Study on Business Faculty Members in Jordanian Universities). Computer in Human Behavior Journal.

Jimenez, D.J. and Valle, R.S. 2011. Innovation, Organizational Learning, and Performance. Journal of Business Research 64.

Lis, E.Y. 2016. Job Satisfaction as an Intervening Variable of Self Efficacy an Employee Performance. International Journal of Academic Research in Business and Social Sciences, Vol. 6(7).

Nikpour, A. 2017. The Impact of Organizational Culture on Organizational Performance: The Mediating Role of Employee's Organizational Commitment. International Journal of Organizational Leadership, Vol. 6(1) 65-72.

Pavlica, K. 2014. Versatile Leadership and Organizational Culture. Department of Managerial Psychology and Sociology. Skoda Auto University, Mlada Boleslav, Czech Republic.

Saeed, R. et al. (2013). Factors Affecting the Performance of Employees at Work Place in the Banking Sector of Pakistan. Middle-East Journal of Scientific Research Vol. 17 (9): 1200-1208.

Salman, M, et al. 2016. Impact of Self Efficacy on Employee's Job Performance in Health Sector of Pakistan. American Journal of Business and Society, Vol. 1(3) 136-142.

Syafii, L. I., et al. 2015. The Role of Corporate Culture and Employee Motivation as a Mediating Variable of Leadership Style Related with the Employee Performance (Studies in Perum Perhutani).
Procedia Social and Behavioral Sciences. Elsevier Ltd.

Tims, et al. 2013. Daily Job Crafting and the Self Efficacy Performance Relationship. Journal of Managerial Psychology Vol. 29 No. 5.

Wibowo. 2012. Manajemen Kinerja. Jakarta: Rajawali Pers. 